\title{
ENERGY POTENTIAL OF SOLID WASTE GENERATED AT A TERTIARY INSTITUTION: ESTIMATIONS AND CHALLENGES
}

\author{
Adelere E. Adeniran ${ }^{1}$, AbdulGaniyu O. Adelopo ${ }^{2, *}$, Adetinuke T. Aina ${ }^{2}$, Afolasade T. Nubi ${ }^{2}$ \\ and Oluwatobi O. Apena ${ }^{3}$
}

${ }^{1}$ Department of Civil \& Environmental Engineering, University of Lagos, Nigeria
${ }^{2}$ Works \& Physical Planning Department, University of Lagos, Nigeria
${ }^{3}$ Department of Electrical and Electronic Engineering, University of Lagos, Nigeria
Article Info:
Received:
10 April 2019
Revised:
10 June 2019
Accepted:
02 July 2019
Available online:
01 August 2019
Keywords:
Waste to energy
Residual waste
Calorific value
Moisture content
Municipal solid waste

\begin{abstract}
Waste to energy (WtE) refers to any treatment process that creates energy in the form of electricity or heat from a waste source. This research reviews the potential uses of municipal solid waste generated at the University of Lagos, Akoka campus as a sustainable energy source for the tertiary institution. Waste characterization study of the residual waste at the University's sorting centre was conducted to determine the amount, composition and physical properties of the waste. A novel compositional trending ratio (CTR) was used to evaluate the possible calorific variation in samples using ASTMD3286-77 method. A validation of the experimental results was carried out using energy estimation model described by Smith and Scott (2005) and World Bank (1999). The major components of the residual waste were mainly polythene materials $(24 \%)$, inert $(30 \%)$, organic waste $(15 \%)$, and paper $(15 \%)$. The average calorific value of $17.23 \mathrm{MJ} / \mathrm{kg}$ and moisture content of $41.3 \%$ could potentially generate $34,787 \mathrm{kWh}$ daily (about $48.32 \%$ of the $72,000 \mathrm{kWh}$ energy demand of the University). There was no significant statistical difference between experimental energy estimation of samples and model energy values $(p<0.001)$ and a Relative Percent Difference (RPD) $<3 \%$ (experimental energy $1112.1 \mathrm{MJ} / \mathrm{Kg}$, model value $1108.3 \mathrm{MJ} / \mathrm{Kg}$ ). The major challenge to adopting WtE technology is the gap in daily tonnage of waste generated which can be overcome through collaborative solid waste management program with closed neighborhood and tertiary institution. The findings provide resourceful information on sustainable management of waste generated for a typical tertiary institution.
\end{abstract}

\section{INTRODUCTION}

Energy generation is pivotal to economic, social and intellectual development of any nation. The drive towards meeting the global energy demand has created immense challenges with $90 \%$ of energy generated from fossil fuels having attendant risks to human health and the environment (Cheng and $\mathrm{Hu}, 2010$ ). One of the ways of sustainable energy generation is through Waste to energy (WtE). White refers to any treatment process that creates energy in the form of electricity or heat from waste (Pour et al., 2018). The creation of energy from waste in the form of gas, liquid or solid have the potential of reducing over dependent on fossil fuels, hence viable alternative method to managing most municipal solid waste (MSW) and residual waste. What technologies have the potential to reduce the volume of the original waste by 90 per cent, depending on the waste composition of waste used and the advan- cement in the technology deployed (Cheng and $\mathrm{Hu}, 2010$ ). There are over 2000 conventional WtE facilities worldwide using more than 130 million tons MSW each year to produce energy. $64 \%$ of world's WtE is achieved through waste incineration plant while other forms of renewable energy from waste are generated from landfill gas (LFG) and anaerobic digestion of organic waste (Pour et al., 2018). Waste incinerators have been successfully deployed in many developed countries in Europe, Asia and the UK. The US generates about 14,000 GWh annually from about 29 million tonnes of MSW through WtE incineration facilities (Stocker, 2013).

Most developing countries have huge challenges in the use of white incinerator plants due to the large investments and operating costs, but more importantly is the absence of profound knowledge on waste generation and composition which form the bedrock in the choice and design of WtE plant. According to World bank technical guideline for 
WtE plant, 1999, the major preconditions factors to WtE plant before the financial implication assessment are: i) A mature and well-functioning waste management facility operated for a number of years, ii) disposal of solid waste at a controlled and well operated landfill iii) The supply of combustible waste at a stable volume which at least $90 \%$ of daily capacity of the WtE facilities iv) The average lower calorific value must not fall below $6 \mathrm{MJ} / \mathrm{kg}$.

Although, Nigeria is richly endowed with various energy resources: crude oil, natural gas, coal, biomass, solar, wind, hydro resources, yet her development has been negatively impacted by the gap of energy demand and supply to both formal and informal sectors of the country (Oyedepo, 2012). The nation currently generates about $3,920 \mathrm{MW}$ with per capita power capacity of $28.57 \mathrm{~W}$ which is not enough to meet even the domestic consumption demand (Oyedepo, 2012, Ibikunle et al., 2019). Most tertiary institution's energy demands are higher than the normal municipal settlement with huge energy needed to carry-out continuous research.

An energy deficit in these institutions from the national grid is often supplemented through the independent generation of electricity by heavy generators which increase the environmental pollution and the use of fossil fuel. Sustainable means of alternative energy generation for tertiary institution could help reduce these negative environmental impacts.

University communities as model mini cities with a known potential population, activities and lifestyle provide an opportunity for structural evaluation of the WtE associated conditions. Cultural differences, climate, and socioeconomic conditions are expected to have a limiting influence on waste composition variation within a campus.

For a successful outcome of what project accurate data on the future trends in waste quantities and characteristics will inform the basis for the design of the plant. Most university community's growth rate is strategically monitored by local and international standard for effective running (Alshuwaikhat and Abubakar, 2008).

University community can therefore represent a model community suitable for the evaluation of WtE potential especially in developing countries having challenges with solid waste data and record keeping.

The heating values of MSW largely depend on the lower calorific value which is the heat required to vaporize any free water in the waste and while providing for any dilution effect of non-combustible ash in the waste (cooper et al., 1999). Estimated calorific values of MSW can be determined using established predictive mathematical models for each waste sample type or by experimental procedures (Menikpura et al., 2007). Data on the Higher Heating Value of MSW have been widely published, but with concern over the disparity range between experimental determination and predictive model (Kathiravale et al., 2003a).

Kalantarifard et al., 2011 had observed that experimental determination of calorific energy with a bomb calorimeter using 0.5 to $1 \mathrm{~g}$ of waste sample may not adequately account for the possible variance in MSW composition. While Menikpura et al., 2007 had successfully validated experimental determination of energy variation in MSW composition of Kandy, Sri Lanka using Modified Dulong and Shafizadeh model energy values.

A good estimation of the impact of variation in waste composition and volume is critical values for the determination of waste energy estimation and the operation of what plant. An extreme waste composition of predominantly sand and plastics could adversely affect the operation of WtE despite relatively high average lower calorific value. Establishment of an evaluation scheme to determine the variation trends in waste composition and generation are often challenging in proposing WtE plant.

This research proposed a novel compositional trending ratio (CTR) to evaluate the possible calorific variation in waste generated on a university campus. An experimental and model predictions energy evaluation system was used with the view to determine energy potential inherent in the wastes.

\section{MATERIALS AND METHODS}

\subsection{Sampling area}

University of Lagos, Akoka campus is located in the Western part of Lagos, Nigeria. It is one of the major University campuses in Nigeria with an estimated 561 hectares of land area hosting 10 faculties, 330 staff housing units, 15 students' hostels and several administrative and academic buildings. Detailed demography of the University is as presented by Adeniran et al. (2017). In order to provide a sustainable environment suitable for teaching, research and social life, the University of Lagos, Akoka campus, embarked on reformation of its environmental and waste management system by dividing the campus into zones and employing private waste managers to ensure effective waste collection.

Two private waste managers were employed to collect waste for zone A, B, C and D which were mainly academic and residential areas respectively (Figure 1). The waste is disposed at the University Sorting Centre where each waste manager sorts the recyclable wastes and packages it for onward transfer to recycling company. The recycling program has made available real-time data on solid waste generation trends in the University as reported by the characterization studied carried-out to determine the compositional trend in the fresh waste disposed (Adeniran et al., 2017). This study showed that waste recovery will be needed for the University to achieve a zero waste goal.

Wastes not having local recycling market or not effectively separated (about $98 \%$ of total waste generated) are left on the sorting field (about $3189 \mathrm{~m}^{2}$ ) as residual waste. The residual waste is finally disposed onto the landfill.

\subsection{Sampling procedure}

Sampling of the residual waste was carried out using systematic gridding procedures as described by Resource Conservation Reservation Authority Waste Sampling Draft Technical Guideline, (USEPA, 2002). The site was gridded into ten sampling cells with each cell of approximately $318.9 \mathrm{~m}^{2}$. Each cell was located using the Global Position System (GPS) device and an average of $5 \mathrm{~kg}$ sample collected from each sampling point. Samples were collected 


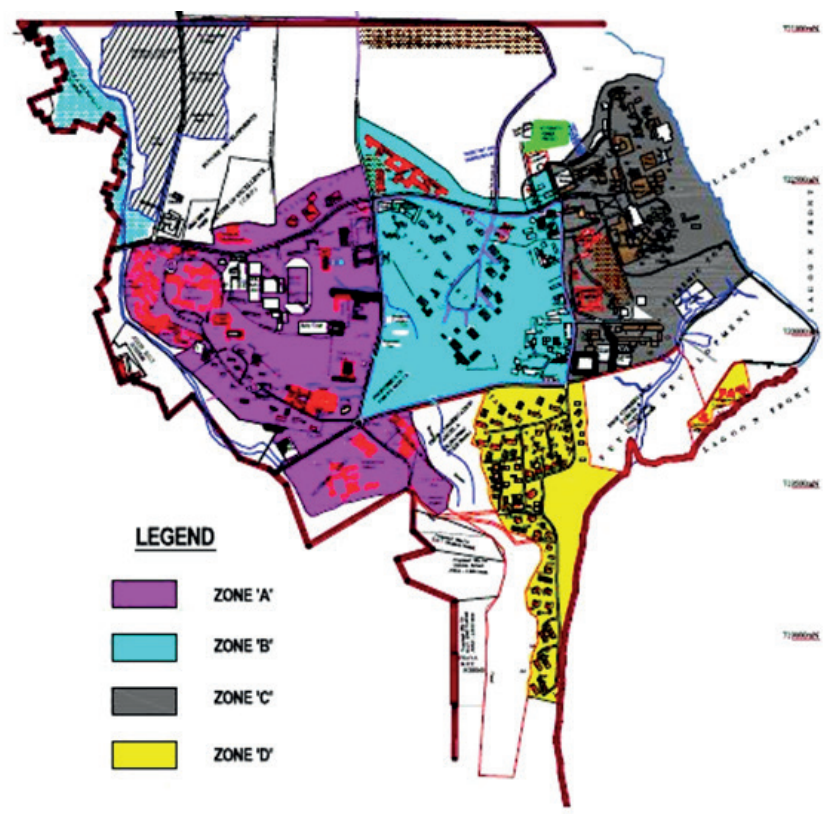

FIGURE 1: Map of University of Lagos, Akoka campus showing solid waste management zones.

using decontaminated hand shovel and placed in labeled polythene bags for onward transfer to the laboratory for analysis. Samples were collected between April and August 2017 at the sorting centre.

\subsection{Moisture Content of sample}

The moisture content of samples was evaluated using ASTM D3173 procedure (ASTM, 1988). Samples were dried in the oven at $105^{\circ} \mathrm{C}$ till constant weight was attained and the \% moisture content of samples determined as thus:

$\%$ moisture content $(M C)=\frac{W W-D W}{W W} \times 100$

Where $W W$ is the weight of wet sample and $D W$ is the dried sample weight.

The dried samples were separated into classes based on physical identification of the types of waste. Waste classifications were in line with IPPC, 2009 and Adelopo et al., 2017 municipal waste grouping.

\subsection{Calorific value determination}

The Calorific Value (CV) of the residual waste is expressed as energy content (E), or heat value, released when burnt in air (García et al., 2012). The Net Calorific value (NCV), or Lower Heating Value (LHV) was used in the evaluations of sample. The NCV was measured in terms of the energy content per unit mass (García et al., 2012).

$E(M J)=M \times N C V$

Where $N C V$ is net calorific value and $M$ is the sample mass.

The net calorific energy content of each sample was determined using ASTM E711-87- Standard Test Method for Calorific Value of Refuse-Derived Fuel by Bomb Calorimeter (ASTM, 2004), using oxygen bomb calorimeter (CAL2K model). The calorimeter was calibrated using $0.5 \mathrm{~g}$ of benzoic acid before sample analysis. $0.5 \mathrm{~g}$ sample was weighed using analytical weighing balance and placed in the combustion chamber of the calorific analyser. The calorific values of samples were determined by burning the weighed sample in oxygen bomb calorimeter under controlled pressure of $3 \mathrm{MPa}$. The energy values of samples were determined in triplicate and the average value taken after proper allowance for thermometer and thermochemical corrections. Accounting for possible variation in waste components is critical to the determination of MSW calorific value (World bank, 1999). Kalantarifard et al., 2011 had observed that experimental determination of calorific energy with a bomb calorimeter using $0.5 \mathrm{~g}-1 \mathrm{~g}$ of sample may not adequately account for the possible variance in MSW composition. To this end, the average \% compositional ratio of the residual waste was determine and the major constituents of the residual waste were varied at definite \% compositional ratio (0:0\% content, PC: present $\%$ composition, $50: 50 \%>$ PC) refers to as Compositional Trending Ratio (CTR) to determine the energy content trend for various waste components. The variation in the waste components was designed to accommodate different possible waste generation pattern in the institution which may be influenced by occasion on campus-graduation and matriculation ceremonies (February/March) that could increase plastic bottles and organic components of waste. Also, during vacation (September-November) which could reduce paper component in the generated waste. A total of 12 composite representative samples of defined \% compositional ratios were homogenized before analyzed.

The total estimated potential energy per day for each composite sample was determined as thus:

$E=N C V i * M_{p d}$

Where $M_{p d}$ is the mass of average residual waste generated on campus per day.

Energy in term of kWh per day (Eeq) was determined using equation 4 .

$E e q=\frac{1}{3.6 \times 10^{1}} * E$

Annually waste generation projection was determined according to the World Bank's 1999, model:

Generated waste $=P P(1+G R p p)^{n} X w c\left(1+G R_{K}\right)^{n}$

Where $P P$ is the present population, GR the growth rate and $w c$, waste generation per capita $K F$, is the actual key figure, and $n$ the forecast year.

The energy potential of residual waste determined through oxygen bomb calorimeter was compared with energy potential estimation model described by Smith and Scott (2005), and World Bank (1999). The models determined average energy content for each type of waste which is cumulated per composite waste sample.

\subsection{Data analysis}

A correlation study using Statistical Package for Social Sciences 21 (SPSS) was deployed to determine the relationship between the components of samples, moisture content and the calorific values of samples. 


\section{RESULTS AND DISCUSSION}

\subsection{Residual composition}

Fresh wastes are wastes evaluated on the first day of disposal at the sorting centre while residual waste are wastes left at the sorting centre for a period of 8-12 weeks after disposal and sorting of needed recyclable waste. The major components of the residual waste were mainly polythene materials $(24 \%)$, inert $(30 \%)$, organic waste $(15 \%)$, and paper (15\%) representing $74 \%$ of total waste composition. Figure 2 compares the compositional trend between the fresh waste disposed and residual waste intended for energy recovery. Major non-biodegradable component remain constant in both cases (polythene bags $24 \%$, e-waste $0 \%$, and glass $2 \%$ ) despite the difference in the sampleFresh waste and residual waste. This could indicate the regular generation trend of these wastes on campus and also that the recycling programme had not adequately cater for these set of waste. Conversely, increment in inert waste ( $8 \%$ in fresh waste to $30 \%$ in residual waste) may be due to the decomposition of other degradable waste like paper, food and textile which could mix up with the soil component of waste. Degraded waste were observed to influence the increase in the \% composition of fine/soil component of disposed municipal waste by Sormunen et al. (2008) Jain et al. (2014) and Quaghebeur et al. (2013). An independent sample t- test was used to evaluate similarity between the compositional properties of the fresh disposed waste and the residual waste. Of the 12 constituents evaluated, 4 classes (inert, organic matter, plastic and textiles) showed a significant statistical difference $(p<0.05)$.

\subsection{Percentage Moisture content}

The \% moisture content (MC) of samples is presented in Figure 3. The MC of samples varied (within 21\% and 69\%) with $60 \%$ of the samples having MC below $50 \%$. The moisture content of sample could be attributed to the effect of

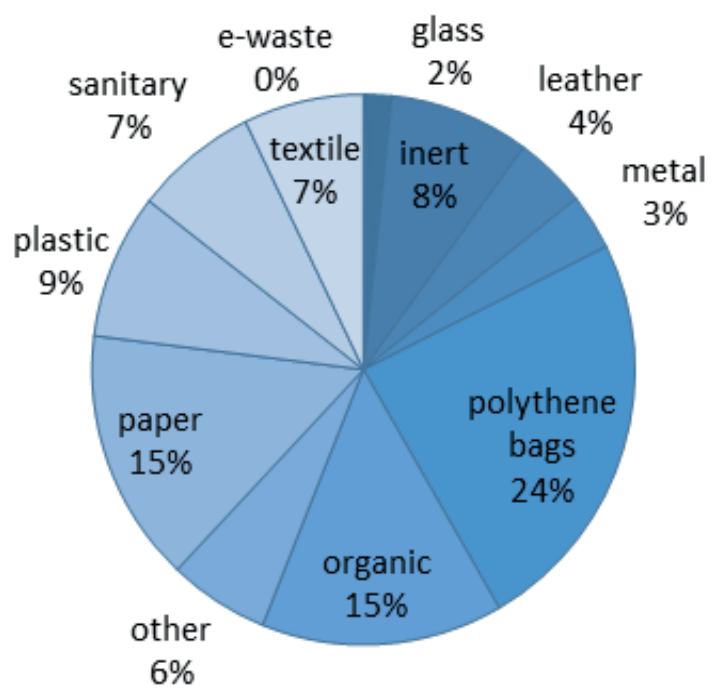

Fresh composition constituent wastes in each of the samples as presented in the supplementary data. This was investigated using a correlation studies between $\%$ moisture content and waste component (Table 1). The study shows that plastic, polythene and inert components had a strong negative statistical correlation of $-0.611,-0.561,-0.644$ with the $P$ value at $0.01,0.01$ and 0.05 respectively. This indicates that moisture content decreases with increased content of these sets of waste. Researchers have attributed the non- porous nature of polythene and plastic material as a major compositional factor affecting the moisture content of composite municipal waste (Quaghebeur et al., 2013 and Adelopo et al., 2017). Cheng et al. (2007) had identified high moisture content of waste as having significantly effect on its combustibility. The average \% moisture content of samples $(41.3 \%)$ is within viable condition for waste to energy. This meets the basic moisture content criteria of less than $45 \%$ as reported by Cheng and $\mathrm{Hu}$ (2010) and central pollution control, (2016). It is also lower than moisture content of municipal waste incinerated in China and Malaysia (55\%) and Philippines (48\%) (Kathirvale et al., 2003, Cheng and Hu, 2010, World bank, 1999).

\subsection{Calorific value}

Table 2 presents the variations in the waste components of each composite samples and the energy obtainable from the samples. The highest calorific values $(23 \mathrm{MJ} / \mathrm{kg}$ ) was recorded with polythene component at the highest possible $\%$ composition ratio (50\% above the present composition) while the lowest calorific values $(11 \mathrm{MJ} / \mathrm{kg})$ was obtained when inert constituent was varied at $50 \%$ above the present $\%$ composition of residual waste. All the possible variations evaluated ( $0 \%$ to $50 \%$ of polythene, organic waste, paper and inert components) were above the minimum energy level of $6 \mathrm{MJ} / \mathrm{Kg}$ for viable WtE feed (World bank, 1999).

Figure 4 compares the experimental energy values of residual waste determined using Oxygen bomb calorime-

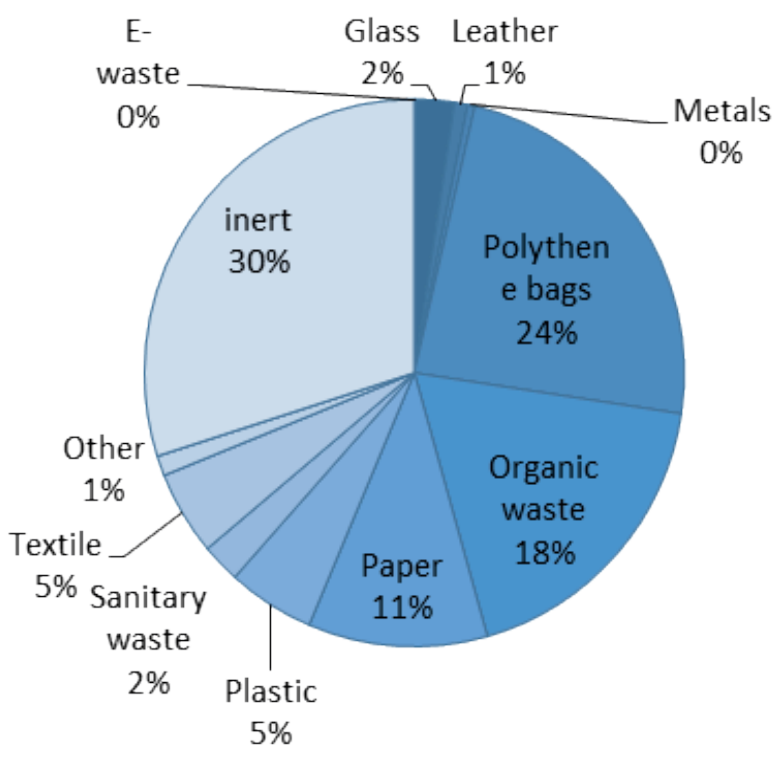

Residual composition

FIGURE 2: Comparing the compositional trends in the fresh and residual waste of the University. 


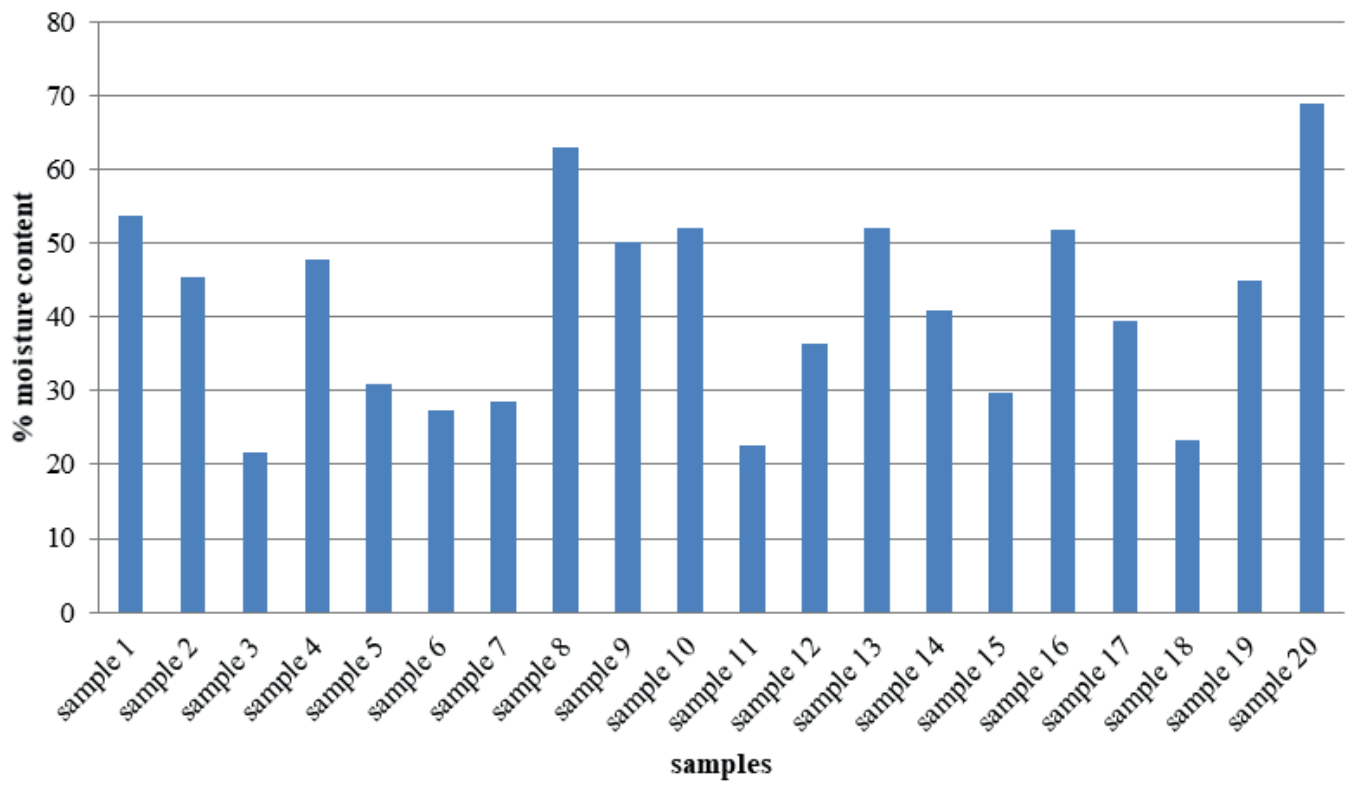

FIGURE 3: Moisture content of samples.

ter with energy estimation model described by Smith and Scott (2005) and World bank (1999). Both methods indicated strong agreement in the energy potential of the residual waste evaluated (experimental energy $1112.1 \mathrm{MJ} / \mathrm{Kg}$, model value $1108.3 \mathrm{MJ} / \mathrm{Kg}$ ) with a low relative percent difference of $3 \%$. This further reinforces the energy potential in the residual waste samples. It also implies that the applied composite formation method using \% composition of waste can reduce the possible variation associated with experiment determination of energy content of waste sample. No significant statistical difference between experimental energy values and the values of energy obtained via model energy estimate with $\mathrm{P}<0.001$.

Table 3 presents the correlation studies between $\%$ compositional ratio in waste component and calorific value. The result shows that polythene and inert components have significant effects on the calorific value of the samples. While there is a strong positive statistical correlation between increasing \% composition of Polythene component and calorific value ( 0.646 with $P$ value of 0.05$)$, inert component had a negative statistical correlation ( -0.586 with $P$ value of 0.01 ) with the calorific value of samples. This implies that increase in polythene increase the calorific value of the waste and increase in inert waste decreases calorific energy potential of the waste.

The energy recovery model further confirms the effect of polythene and inert materials on the energy value of residual waste being responsible for $61 \%$ (39\% from poly-

TABLE 1: Correlation studies of waste components and moisture content.

\begin{tabular}{|c|c|c|c|c|c|c|c|c|c|c|c|c|c|}
\hline & E-waste & Glass & Leather & Metal & Polythene & Organic & Paper & Plastic & Sanitary & Textile & Other & Inert & Moisture \\
\hline E-waste & 1.000 & -.090 & .075 & .020 & -.138 & -.058 & -.189 & .063 & .195 & -.114 & .120 & .170 & .019 \\
\hline Glass & & 1.000 & -.413 & -.128 & .089 & -.029 & -.364 & -.151 & .217 & .091 & .164 & .165 & -.093 \\
\hline Leather & & & 1.000 & -.202 & -.095 & -.055 & .329 & -.106 & -.039 & .091 & $-.486^{*}$ & $-.468^{\star}$ & .273 \\
\hline Metal & & & & 1.000 & -.138 & .193 & $-.462^{\star}$ & .172 & .244 & .207 & .379 & .420 & -.126 \\
\hline Polythene & & & & & 1.000 & -.224 & -.111 & $.630^{\star *}$ & -.165 & -.187 & .188 & .337 & $-.611^{* *}$ \\
\hline Organic & & & & & & 1.000 & -.020 & -.347 & .059 & .021 & .304 & -.167 & .192 \\
\hline Paper & & & & & & & 1.000 & -.035 & $-.453^{\star}$ & -.043 & -.443 & $-.520^{*}$ & .146 \\
\hline Plastic & & & & & & & & 1.000 & -.139 & .132 & .248 & $.542^{*}$ & $-.561^{*}$ \\
\hline Sanitary & & & & & & & & & 1.000 & .104 & .290 & .248 & .009 \\
\hline Textile & & & & & & & & & & 1.000 & .079 & .056 & .101 \\
\hline Other & & & & & & & & & & & 1.000 & .405 & -.094 \\
\hline Inert & & & & & & & & & & & & 1.000 & -.664 * \\
\hline Moisture & & & & & & & & & & & & & 1.000 \\
\hline
\end{tabular}

** Correlation is significant at the 0.01 level (2-tailed)

* Correlation is significant at the 0.05 level (2-tailed) 
TABLE 2: Variation in the waste components of each composite samples and energy obtainable.

\begin{tabular}{|c|c|c|c|c|c|c|}
\hline \multirow{2}{*}{$\begin{array}{l}\text { sample code based } \\
\text { on varied component }\end{array}$} & \multicolumn{5}{|c|}{$\%$ composition of sample } & \multirow{2}{*}{$\begin{array}{l}\text { Energy content } \\
\quad(\mathrm{MJ} / \mathrm{Kg})\end{array}$} \\
\hline & Polythene & Organic waste & Paper & Inert & Others & \\
\hline $\mathrm{PE}_{0}$ & $0 \%$ & $24 \%$ & $14 \%$ & $39 \%$ & $22 \%$ & 13.28 \\
\hline $\mathrm{Pe}_{\mathrm{pc}}$ & $24 \%$ & $18 \%$ & $11 \%$ & $30 \%$ & $17 \%$ & 18.25 \\
\hline$P E_{50}$ & $32 \%$ & $16 \%$ & $10 \%$ & $27 \%$ & $15 \%$ & 20.36 \\
\hline $\mathrm{OW}_{0}$ & $29 \%$ & $0 \%$ & $13 \%$ & $37 \%$ & $21 \%$ & 16.07 \\
\hline $\mathrm{OW}_{\mathrm{pc}}$ & $24 \%$ & $18 \%$ & $11 \%$ & $30 \%$ & $17 \%$ & 17.95 \\
\hline $\mathrm{OW}_{50}$ & $22 \%$ & $25 \%$ & $10 \%$ & $28 \%$ & $16 \%$ & 15.94 \\
\hline $\mathrm{PP}_{0}$ & $27 \%$ & $20 \%$ & $0 \%$ & $34 \%$ & $19 \%$ & 13.66 \\
\hline $\mathrm{PP}_{\mathrm{pc}}$ & $24 \%$ & $18 \%$ & $11 \%$ & $30 \%$ & $17 \%$ & 18.02 \\
\hline $\mathrm{PP}_{50}$ & $23 \%$ & $17 \%$ & $16 \%$ & $28 \%$ & $16 \%$ & 15.14 \\
\hline $\mathrm{IN}_{0}$ & $34 \%$ & $26 \%$ & $16 \%$ & $0 \%$ & $24 \%$ & 20.12 \\
\hline$I N_{p c}$ & $24 \%$ & $18 \%$ & $11 \%$ & $30 \%$ & $17 \%$ & 17.95 \\
\hline $\mathrm{IN}_{50}$ & $21 \%$ & $16 \%$ & $10 \%$ & $39 \%$ & $15 \%$ & 11.62 \\
\hline
\end{tabular}

PE: polythene / OW :Organic waste / PP: paper / IN: inert / 0 :0\% content / PC: present \% / composition, 50: $50 \%>$ PC

thene and $22 \%$ from inert) of the potential energy from the residual waste (Table 4). Managing the variation in these components of waste would affect the energy potential of waste recoverable from the residual waste. Cheng et al., 2007 had observed that low energy content waste (4-6.7 $\mathrm{MJ} / \mathrm{Kg}$ ) from food waste reduced the energy generation in some WtE plant in China while higher energy generation were obtained from WtE in Europe and USA due to relative higher energy content waste like polythene materials.

Sources of waste variation in a modelled community like the University campus are often limited to the activities on campus which can be evaluated. The degrees in waste variation are also minimal compared to the variation expected in MSW (Okeniyi et al., 2012). Level of education, income statute, life style are majors factors influencing the type of waste generated (Hoornweg and
Bhada-Tata, 2012). Irwan et al. (2011) had attribute generation of large quantity non-biodegraded waste to life style of people having tertiary education and are above average income earners which conform to most population within the University community. Major events on campus that could induce waste variation are expected to increase energy potential of waste due to possible generation of more non-biodegraded waste (paper, plastic and polythene). Report of some tertiary institutions waste characterization studies as presented by Armijo de Vega et al. (2008), Smyth et al. (2010) and Okeniyi et al. (2012) strongly confirm the availability of higher quantities of non bio-gradable waste.

The energy potential of residual waste generated daily on campus is estimated as $139,146 \mathrm{kWh}$ as presented in Table 4. According to Kathiravale et al., 2003 and World

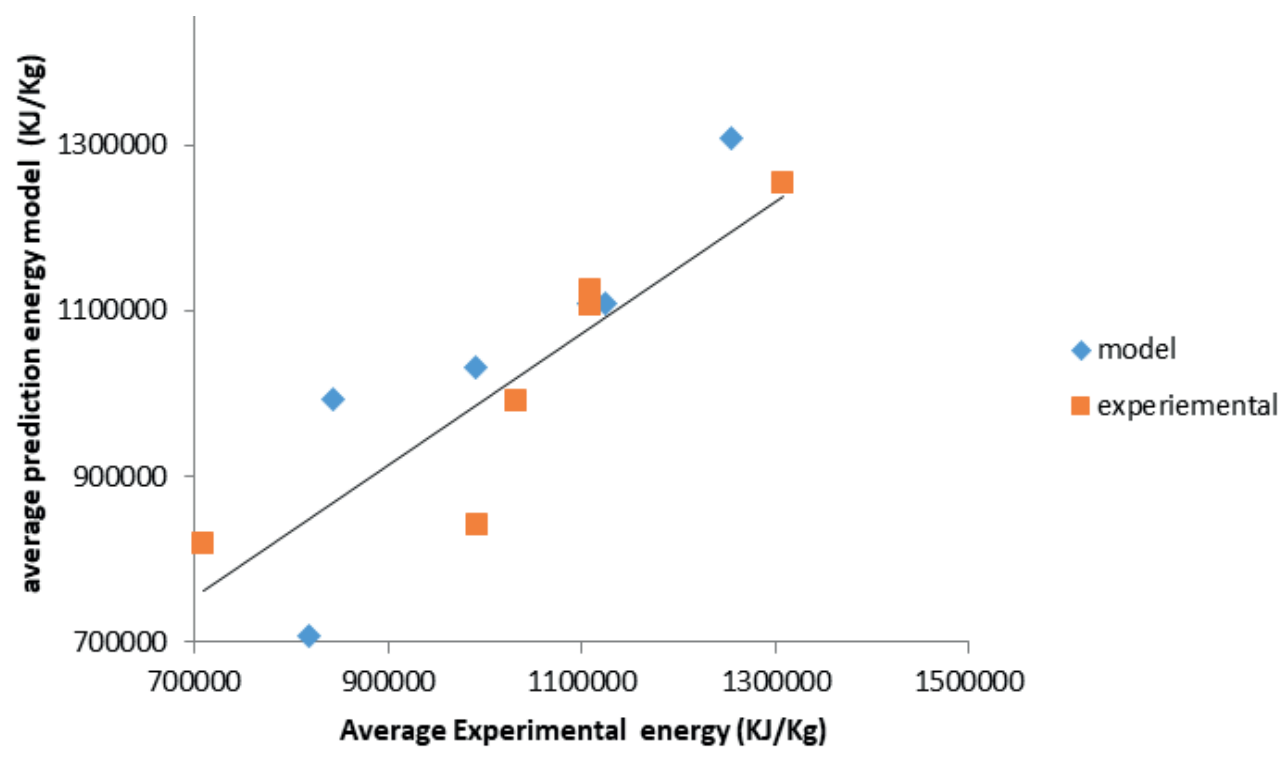

FIGURE 4: Variation in the waste components of each composite samples and energy obtainable. 
TABLE 3: Correlation studies of major components of the samples and calorific values.

\begin{tabular}{|c|c|c|c|c|c|}
\hline & Polythene & Organic & Paper & Inert & Calorific \\
\hline Polythene & 1.000 & -.194 & -.246 & -.194 & $.646^{* *}$ \\
\hline Organic & & 1.000 & -.194 & -.153 & -.133 \\
\hline Paper & & & 1.000 & -.194 & -.148 \\
\hline Inert & & & & 1.000 & $-.586^{*}$ \\
\hline Calorific & & & & & 1.000 \\
\hline
\end{tabular}

** Correlation is significant at the 0.01 level (2-tailed)

* Correlation is significant at the 0.05 level (2-tailed)

bank, 1999 , only $50 \%$ to $25 \%$ of the total energy potential is recoverable depending on conversion techniques. The residual waste could potentially generate $34,787 \mathrm{kWh}$ (at $25 \%$ recovery potential) which will be able to power 7000 electric cooker (1000 W rating) of resident member of the institution for 3 hours. It has the potential of reducing the diesel consumption for 2 hours daily. The average diesel consumption for the University's 2250 KVA Cummins generators is at 200 litre per hour. If WtE is harnessed for a month this could cut the carbon print of the university via diesel consumption by $10 \%$. A higher energy potential could have been achieved from the fresh waste disposed $(50,148 \mathrm{KWh}$ per daily using model method) if used directly for WtE. This is due to increase in the \% composition of waste component having high calorific values (plastic, paper textile) compared to the residual waste (Figure 1). The use of fresh disposed waste may, however, undermine the present recycling effort of the University and reduce communal participation in waste management via waste sorting.

The energy content of waste may be adversely affected if the University's construction demolition waste (C\&D waste) is mixed with present composition of waste. Inert waste content tends to lower the calorific energy content of the generated waste. The University will need to ensure an effect controlled measure to prevent disposal of its C\&D along with other waste.

\subsection{Volume of Generation Projection}

Waste forecast over the life span of a WtE plant (15 to 20 years) is essential in assessing energy generation feasibility. During this period, apart from change in government policy on waste management which may influence waste management on campus, population growth of the institution is assumed to be the major factor that could influence waste generation and composition. Annually waste generation was determined in accordance with University's population growth rate as content in the University Master Plan. The trends in the data of waste generated and characterized on campus for the past three years were used as the key factors in projection analysis( per capita generation at $0.58 \mathrm{~kg} /$ person/day).

Table 5 presents the estimated waste generations projection for fifteen years. The data shows a possible growth in the power recoverable from waste by $16 \%(34,787 \mathrm{kWh}$ per day to $41,302 \mathrm{kWh}$ per day) within fifteen years at $25 \%$ efficiency. This provides a good incentive that increase in waste generation as a result of increase in population can be sustainably utilize for the community benefit.

However, the daily waste generated at the University of Lagos campus (32.2 tons to 38.4 tons) for the entire duration fall short of the minimum requirement of $250 \mathrm{t} /$ day for eco-friendly WtE plants (Cheng and Hu, 2010 and 2007). This major challenge can however be managed with collaboration with four other major tertiary institutions which are in close proximity to the University. These tertiary institutions pay tipping charges to dispose their waste at the municipal landfill. Presentation of a cost-analysis benefit could attract the interest of these tertiary institutions having potentially similar waste generation pattern. Waste generation and characterization of each tertiary will be needed to ascertain their compatibility for the program.

More Universities in developed countries are leveraging on the waste generated on campus and within their immediate community to generate renewable energy for the campuses' sustainability programs. University of lowa, US, had set 2025 to end the present use of coal plant and

TABLE 4: Caloric value of waste determined from model calorific value and \% energy contribution of each waste type.

\begin{tabular}{|c|c|c|c|c|}
\hline Waste type & Quantity of waste (g) & $\begin{array}{l}\text { Model Calorific } \\
\text { Value(MJ/Kg) }\end{array}$ & $\begin{array}{c}\text { Calorific value per } \\
\text { waste type }(\mathrm{MJ} / \mathrm{Kg})\end{array}$ & $\begin{array}{c}\text { \% Energy contribution } \\
\text { per waste type }\end{array}$ \\
\hline E-waste & 44.1 & 0 & 0 & 0 \\
\hline Glass & 1425.3 & 0 & 0 & 0 \\
\hline Leather & 491.8 & 22.5 & 11.066 & $1 \%$ \\
\hline Metals & 263.3 & 0 & 0 & $0 \%$ \\
\hline Polythene bags & 14655.7 & 27.3 & 400.1 & $36 \%$ \\
\hline Organic waste & 11248 & 6.7 & 75.4 & $7 \%$ \\
\hline Paper & 6618.9 & 17.5 & 115.8 & $10 \%$ \\
\hline Plastic & 3214.2 & 45 & 144.6 & $13 \%$ \\
\hline Sanitary waste & 1430.7 & 15 & 21.5 & $2 \%$ \\
\hline Textile & 3070.8 & 19 & 58.3 & $5 \%$ \\
\hline Other & 734 & 6.7 & 4.9 & $0 \%$ \\
\hline inert & 18439.8 & 15 & 276.6 & $25 \%$ \\
\hline Total & 61636.6 & & 1108.3 & $100 \%$ \\
\hline
\end{tabular}


TABLE 5: Waste generation projection and potential energy contente.

\begin{tabular}{|c|c|c|c|c|c|c|}
\hline Year & Population & $\begin{array}{c}\text { Generation } \\
\text { per day }(\mathbf{K g})\end{array}$ & $\begin{array}{l}\text { Quantity of } \\
\text { residual waste for } \\
\text { recovery }{ }^{\#}(\mathrm{Kg})\end{array}$ & $\begin{array}{l}\text { Calorific value per } \\
\text { day }(\mathrm{MJ} / \mathrm{Kg})\end{array}$ & $\begin{array}{l}\text { Equivalent in kWh } \\
\text { per day }\end{array}$ & $\begin{array}{c}\text { Recoverable } \\
\text { energy at } 25 \% \\
\text { efficiency(KWh }\end{array}$ \\
\hline 2017 & 55695 & 32303 & 29073 & 500927 & 139146 & 34787 \\
\hline 2018 & 56363 & 32690 & 29421 & 506930 & 140814 & 35203 \\
\hline 2019 & 57045 & 33086 & 29777 & 513062 & 142517 & 35629 \\
\hline 2020 & 57739 & 33489 & 30140 & 519306 & 144252 & 36063 \\
\hline 2021 & 58437 & 33894 & 30504 & 525587 & 145997 & 36499 \\
\hline 2022 & 59150 & 34307 & 30876 & 531998 & 147777 & 36944 \\
\hline 2023 & 59867 & 34723 & 31250 & 538446 & 149568 & 37392 \\
\hline 2024 & 60613 & 35155 & 31640 & 545153 & 151431 & 37858 \\
\hline 2025 & 61354 & 35585 & 32027 & 551823 & 153284 & 38321 \\
\hline 2026 & 62123 & 36031 & 32428 & 558734 & 155204 & 38801 \\
\hline 2027 & 62897 & 36480 & 32832 & 565701 & 157139 & 39285 \\
\hline 2028 & 63690 & 36940 & 33246 & 572834 & 159121 & 39780 \\
\hline 2029 & 64479 & 37398 & 33658 & 579930 & 161092 & 40273 \\
\hline 2030 & 65301 & 37875 & 34087 & 587323 & 163145 & 40786 \\
\hline 2031 & 66127 & 38354 & 34518 & 594753 & 165209 & 41302 \\
\hline
\end{tabular}

\# $90 \%$ of daily generation

completely switch to combined heat and power plant (CHPP) which depends on the biomass waste generated on campus and the wood chip waste from closed factories (lowa, 2014). UC Davis college of Engineering uses renewable energy from anaerobic digester to generate $12,000 \mathrm{kWh}$ daily from 50 tons of organic waste generated from within the university campus and cleaned segregated organic waste collected from its neighbourhood (Davis UC, 2014).

WtE can be effectively used to stimulate most University's sustainability programmes in developing countries and drive the larger community participation in sustainable energy activities.

\section{CONCLUSIONS}

The findings have indicated that the waste composition in the University has huge potential energy $(11 \mathrm{MJ} / \mathrm{Kg}-23$ $\mathrm{MJ} / \mathrm{Kg}$ ) with low variations in waste. Polythene and inert are major components which could significantly affect energy values of the waste representing $61 \%$ of recoverable energy potential. The average calorific value of $17.23 \mathrm{MJ} /$ $\mathrm{kg}$ and moisture content of $41.3 \%$ could potentially generate potentially generate $34,787 \mathrm{kWh}$ energy per day. This could cut the carbon print of the university via diesel consumption by $10 \%$. The daily waste generated at the university of Lagos campus (32.2 $t$ ) fall short of the minimum requirement of $250 \mathrm{t} /$ day for eco-friendly WtE plants but could be managed by collaboration with the neighborhood and the other four (4) tertiary institutions around since tertiary community has the potential of generating more non-biodegraded waste. These findings present a systematic procedure to evaluating waste parameters towards a WtE for a model institution. In making a final step to WtE, a further study is necessary to evaluate the economics and environmental impact of the types and location of WtE plants to be deployed.

\section{SUMMARY AND RECOMMENDATION}

The characterization of residual waste in the University campus was carried out in order to determine the energy potential and possible effect of waste composition variation on energy content. A compositional Trending Ratio (CTR) was introduced to evaluate the possible calorific variation in samples using both experimental and predictive models. Our findings indicated that:

- The University waste composition has huge energy potential estimated at 34,787 kWh energy per day with daily waste average calorific value of $17.23 \mathrm{MJ} / \mathrm{kg}$ and moisture content of $41.3 \%$;

- Polythene and inert wastes are major components affecting energy values of the waste representing $61 \%$ of recoverable energy potential;

- The experimental and predictive model energy values showed significant agreement with a low relative percent difference of $3 \%$ for each CTR sample evaluated;

- The daily waste generation capacity of the university campus (32.2t) fall short of the minimum requirement of $250 t$ per day for WtE.

These findings underpin the need for a policy that encourages collaborative waste management among institutions with similarity in waste composition for sustainable waste management.

\section{REFERENCES}

Adeniran A.E. Nubi A.T. Adelopo A.O. 2017. Solid Waste Generation and characterization in the University of Lagos for a sustainable waste management.Waste Management 67, 3-10. 
Adelopo, A.O., Haris, P.I., Alo, B., Huddersman, K., Jenkins, R.O. 2017. Seasonal variations in moisture content and the distribution of total organic carbon in landfill composites: case of active and closed landfills in Lagos, Nigeria. Int. J.Environ. Waste Manage. 20(2), 171-185

Alshuwaikhat, H.M., Abubakar, I. 2008. An integrated approach to achieving campus sustainability: assessment of the current campus environmental management practices. Journal of Cleaner Production 16, 1777-1785.

Armijo de Vega, C., Ojeda Benitez, S., Ramirez Barreto, M.E. 2008. Solid waste characterization and recycling potential for a university campus. Waste Manage. 2(Suppl. 1), S21-S26.

ASTM .1988. Standard Test Method for Determination of the Composition of Unprocessed Municipal Solid Waste, ASTMA standard d 5231-5292 (Reapproved 1998), American Society for Testing and Materials, USA.

ASTM E711-87 .2004. Standard Test Method for Gross Values of Refuse-Derived Fuel by the Bomb Calorimeter (Re-approved), American Society for Testing and Materials, West Conshohocken, PA.

Cheng, H., Zhang, Y., Meng, A., Li, Q .2007. Municipal solid waste fuelled power generation in China: a case study of waste-to-energy in Changchun city. Environ. Sci. Technol. 41, 7509-7515

Cheng, H., Hu Y. 2010. Municipal solid waste (MSW) as a renewable source of energy: Current and future practices in China. Bioresource Technology 101, 3816-3824.

Cooper, C.D.,Kim B., MacDonald J. 1999. Estimating the Lower Heating Values of Hazardous and Solid Wastes, Journal of the Air \& Waste Management Association, 49:4, 471-476, DOI: 10.1080/10473289.1999.10463816.

Jain, P., Powell, J.T., Smith, J.L., Townsend, T.G., Tolaymat, T. 2014. Life-cycle inventory and impact evaluation of mining municipal solid waste landfills. Environmental Science andTechnology. 48(5), 2920-2927.

Central Pollution Control Board. 2016. Selection Criteria for Waste Processing Technologies. Ministry of Environment, Forests and Climate Change. PariveshBhawqan, East Arjun Nagar, Shahdara: Ministry of Environment, Forests and Climate Change.

García, R., Pizarro C., Lavín, A. G., Bueno, J.L.2012. Characterization of Spanish biomass wastes for energy use, Bioresource Technology, $103,249-258$.

Hoornweg, D. and Bhada-Tata, P. 2012. What a waste: a global review of solid waste management, World Bank, Washington DC, USA

Ibikunle R.A, Titiladunayo I.F., Akinnuli B.O., Dahunsi S.O., Olayanju T.M.A. 2019. Estimation of power generation from municipal solid wastes: A case Study of Ilorin metropolis, Nigeria. Energy Reports $5,126-135$.

IPCC - International Panel on Climate Change .2006. Guidelines for National Greenhouse Gas Inventories, Vol. 5-Waste [online] http:// www.ipccnggip.iges.or.jp/public/2006gl/vol5.html(accessed August 2017).

Irwan, D., Basri, E. A., Watanabe, K. 2011. Interrelationship between affluence and household size on municipal solid waste arising: evidence from selected Residential areas of putrajaya. Journal of Asian Scientific Research 2,747-758 lowa 2014.University of lowa timeline path to zero coal,https://www. facilities.uiowa.edu/uem/renewable-energy/ (accessed on November 2017)

Kalantarifard A., Yang, G. S.2011.Energy potential from municipal solid waste IntanjungLangsat Landfill, Johor, Malaysia. International Journal of Engineering Science and Technology 3(12), 8560 8568 .

Kathiravale, S., Muhd Yunu,M., Sopian, K., Samsuddin, A.H. 2003a. Modeling the heating value of Municipal Solid Waste. Fuel 82, 1119-1125

Kathiravale, S., MuhdYunus, M., Sopian, K., Samsuddin, A.2003. Energy potential from municipal solid waste in Malaysia. Renewable Energy $29,559-567$.

Menikpura, S.N.M., Basnayake, B.F.A., Boyagoda, P.B., Kularathne I.W. 2007. Estimations and Mathematical Model Predictions of Energy Contents of Municipal Solid Waste (MSW) in Kandy. Tropical Agricultural Research19, $389-400$.

Okeniyi, J.O. Anwan, E.U., Okeniyi, E.U. 2012. Waste Characterization and Recoverable Energy potential Using waste generated in model community in Nigeria. Journal of Environmental Science and Technology 5(4), 232-240.

Oyedepo, S. O. 2012. On energy for sustainable development in Nigeria. Renewable and Sustainable. Energy Reviews 16, 2583- 2598.

Pour, N., Webley, P. A., Cook, P. J.2018. Potential for using municipal solid waste as a resource for bioenergy with carbon capture and storage (BECCS). International Journal of Greenhouse Gas Control $68,1-15$

Quaghebeur, M., Laenen, B., Geysen, D., Nielsen, P., Pontikes, Y.2013. Characterization of landfilled materials: screening of the enhanced landfill mining potential. J. Clean. Prod. 55, 72-83.

Sormunen, K., Ettala, M. and Rintala, J. 2008. Detailed internal characterisation of two Finnish landfills by waste sampling. Waste Management 28(1), 151-163.

Stocker, T.F.2013. Climate change - the physical science basis. Working Group I Contribution to the Fifth Assessment Report of the Intergovernmental Panel on Climate Change. pp. 2013

Smyth, D.P., Fredeen, A.L., Booth, A.L.2010. Reducing solid waste in higher education: the first step towards 'greening' a university campus. Resource Conservation Recycling 54, 1007-1016.

Davis, U.C. 2014- UC Davis College of engineering biodigester turn campus waste into campusenergy.http://engineering.ucdavis. edu/blog/uc-davis-biodigester-turns-campus-waste-campus-energy/ (accessed December, 2017).

USEPA .2002. RCRA Waste Sampling Draft Technical Guidance. Planning, Implementation and Assessment. EPA530-D-02-002. Office of Solid Waste, Washington, DC.

World Bank.1999. Technical Guidance Report on Municipal Solid Waste Incineration, The International Bank for Reconstruction and Development, Washington, D.C. 20433, U.S.A.

Zhang X., Cheng, X. 2009. Energy consumption, carbon emissions, and economic growth in China. Ecological Economics 68, 27062712. 